\title{
INITIAL EXPERIENCE WITH ENDOSCOPIC ULTRASOUND-GUIDED FINE NEEDLE ASPIRATION OF RENAL MASSES: indications, applications and limitations
}

\author{
Renata Nobre MOURA ${ }^{1}$, Roberto Iglesias LOPES ${ }^{2}$, Miguel SROUGI², \\ Marcos Francisco DALL'OGLIO'2, Paulo SAKAI' and Everson L A ARTIFON'1
}

\begin{abstract}
Context - Tissue sampling of renal masses is traditionally performed via the percutaneous approach or laparoscopicaly. The utility of endoscopic ultrasound to biopsy renal lesions it remains unclear and few cases have been reported. Objectives - To evaluate the feasibility and outcome of endoscopic ultrasound fine needle aspiration of renal tumors. Method - Consecutive subjects undergoing attempted endoscopic ultrasound fine needle aspiration of a kidney mass after evaluation with computerized tomography or magnetic resonance. Results - Ten procedures were performed in nine male patients (median age 54.7 years) on the right $(n=4)$ and left kidney $(\mathrm{n}=4)$ and bilaterally $(\mathrm{n}=1)$. Kidney masses (median diameter $55 \mathrm{~mm}$; range 13-160 mm) were located in the upper pole $(n=3)$, the lower pole $(n=2)$ and the mesorenal region $(n=3)$. In two cases, the mass involved more than one kidney region. Surgical resection confirmed renal cell carcinoma in six patients in whom pre-operative endoscopic ultrasound fine needle aspiration demonstrated renal cell carcinoma. No complications were reported. Conclusions - Endoscopic ultrasound fine needle aspiration appears as a safe and feasible procedure with good results and minimal morbidity.
\end{abstract}

HEADINGS - Kidney neoplasms, diagnosis. Ultrasonography. Endoscopic ultrasound-guided fine needle aspiration.

\section{INTRODUCTION}

Detection of incidental renal masses is increasing because of the widespread use of imaging studies. Over two thirds of renal masses noted incidentally on abdominal CT-scans for non-urological indications are most likely to be renal cell carcinoma (RCC) $)^{(1,4,8,10,15)}$.

Needle biopsy has the potential to decrease the number of unnecessary treatments for benign pathological findings ${ }^{(15)}$. Traditionally, tissue sampling of renal lesions has been performed via the percutaneous approach or laparoscopicaly, in order to characterize radiographically indeterminate lesions, confirm malignancy in not surgical candidates or to guide preoperative planning $\mathrm{g}^{(1,4,10,15)}$.

Few studies addressed this issue and it remains unclear if endoscopic ultrasound (EUS) may have a role in the diagnostic work-up evaluation for $\mathrm{RCC}^{(4)}$. It has been previously demonstrated the utility of EUS to biopsy the prostate and adrenal gland and to evaluate metastatic renal tumors ${ }^{(1)}$. There are few data that describe the safety and feasibility of EUS for biopsy of the kidney.
The aim of this study is to describe the largest single-center case series in the literature and review our initial experience regarding feasibility and outcome of echoendoscopic fine needle aspiration of kidney tumors.

\section{METHODS}

This retrospective study protocol evaluate the usefulness of echoendoscopic ultrasonography with fine needle aspiration (EUS FNA) of renal masses according to recommended guidelines. Written informed consent approved by the Institutional Review Board at Sao Paulo Medical School was obtained before each procedure. EUS guided renal biopsies were performed by a single endosonographer with over 10 years of EUS experience.

All patients had abdominal evaluation with computerized tomography with endovenous contrast or magnetic resonance with gadolinium before the procedure.

Survey for bleeding was performed even in patients with no history of bleeding. Relevant history, 
platelet count, international normalized ratio and partial thrombloplastin time within 1 month of biopsy. Patients were advised to discontinue aspirin and nonsteroidal antiinflammatory drugs 7 to 10 days before the procedure and to stop warfarin in time to establish an acceptable international normalized ratio, which usually requires 5 days. Continuous heparin was stopped 4 hours before the procedure.

Sectorial EUS (echoendoscope GF-UCT 140, Olympus, America Corp., Melville, NY) sectorial array probe with 0.5 $\mathrm{MHz}$, reaching $12.5 \mathrm{~cm}$ was used in this study. The anatomic location of both kidneys allows endosonographic imaging and direct needle access for tissue acquisition ${ }^{(1)}$. The echoendoscope used reaches $12.5 \mathrm{~cm}$ or $7.5 \mathrm{MHz}$ and with the movement of the probe within the duodenum or stomach, this range is sufficient to visualize both kidneys. The right kidney may be approached from the second portion of the duodenum with the EUS transducer rotated laterally. The left kidney may be approached from within the body of the stomach with the EUS transducer facing posterolaterally. The proximity of the EUS tip to the kidney from within the gastrointestinal lumen allows precise location and accurate access for tissue acquisition. Schematization of the echoendoscope, EUS areas of interest for kidney approach (green duodenal area for the right kidney and yellow stomach area for the left kidney), appropriate visualization of the kidney (cortex and medulla), EUS visualization of tumor with needle insertion and aspiration and finally, cytologic aspirate is represented in Figure I. In all cases, three passes with a $22 \mathrm{G}$ needle (Cook Medical) were performed for echoendoscopic fine needle aspiration of renal tumors for adequate cytologic sampling. EUS FNA was performed on an outpatient basis. Only in one case, the procedure

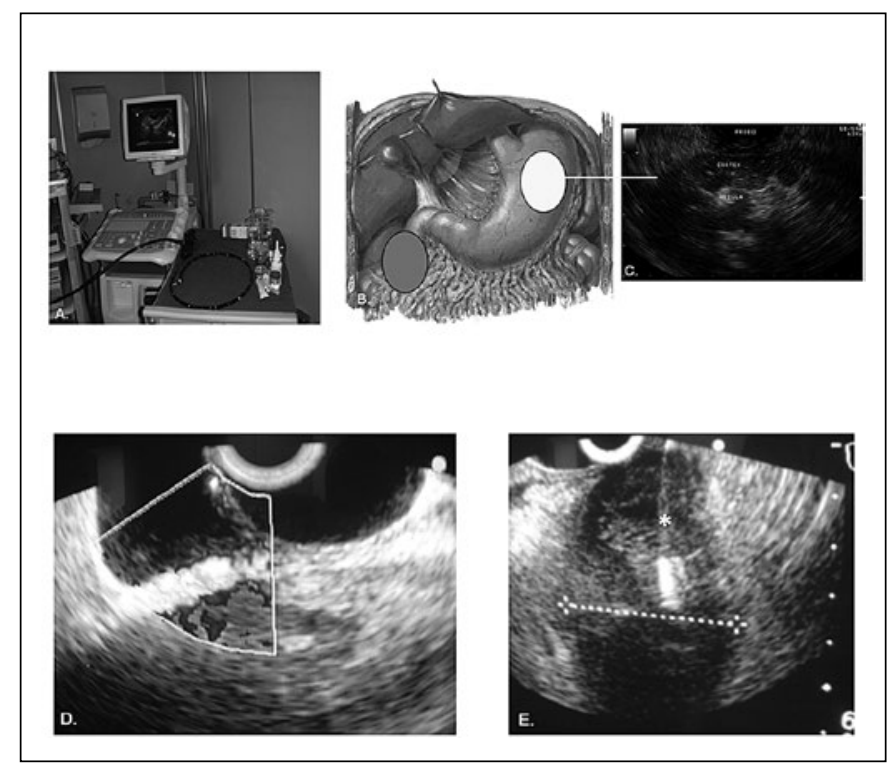

FIGURE 1. A: sectorial endoscopic ultrasound (EUS). B: anatomical location of left (yellow) and right (green) kidneys. C: appropriate visualization of the kidney (cortex and medulla). D: EUS visualization of the tumor and EUS Doppler. E: puncture was done during hospitalization (EUS FNA of bilateral renal masses).

Data collected included patient age and sex, clinical indication of renal biopsy, location and size of renal tumor, EUS FNA cytology, final pathological findings, surgery results, postoperative hospital stay, complications, and clinical follow-up. The criterion standard for diagnosis of any renal mass was histopathological findings from surgical resection. Nephron-sparing procedures were performed depending on tumor site, location and intraoperative evaluation. Cytological analysis was compared with final pathological results.

Histopathological evaluation of the FNA was performed after hematoxylin-eosin staining. Histochemical techniques for surgical specimens included Hale and PAS staining. Immunohistochemistry for the antibodies used for renal cell tumors included pancytokeratin, CK 7, CK20, vimentin, EMA, CD10, CD117 (c-kit), E-cadherin, WT1 and HMB-45, desmin and SMA.

\section{RESULTS}

Ten EUS FNA of renal masses were performed in nine male patients (mean age 56.5 years, median age 54.7 years). The procedure was on the right kidney $(n=4)$, on the left kidney $(\mathrm{n}=4)$ and bilaterally in one. Tumors involved the upper pole $(n=3)$, the lower pole $(n=2)$, the mesorenal region $(n=3)$ and was considered a large mass (more than one kidney region involved) in two cases. Median tumor diameter was $55 \mathrm{~mm}$ (ranging $13 \mathrm{~mm}$ to $160 \mathrm{~mm}$ ).

Clinical indication for CT or MRI abdominal evaluation was macroscopic hematuria $(n=3)$, flank pain $(n=1)$ and abdominal mass $(n=2)$. In the three remaining cases, renal tumors were incidentally discovered. Indication for renal mass biopsy according to clinical guidelines were small renal mass $(n=4)$, suspicion of lymphoma $(n=1)$, suspicion of metastasis $(n=1)$, suspicion of oncocytoma $(n=1)$ in the case of bilateral EUS renal FNA, to distinguish between RCC and nephroblastoma in a young adult patient with renal mass and metastatic disease in one case and finally for histologic subtype analysis to predict response to immunotherapy in a RCC case with brain metastasis. The clinical features are summarized in Table 1.

Final EUS FNA cytology was available in nine of the 10 attempted biopsies. One biopsy failure occurred in a case of a small posterior kidney tumor (biopsy number 4, Table 1). The renal hilum was visualized across the tract of the EUS FNA and although one pass with $22 \mathrm{G}$ needle was attempted, no more attempts were performed and tissue was insufficient. In all other cases, an accurate biopsy was performed which revealed clear cell RCC $(n=5)$, papillary RCC in two aspirates (bilateral tumors in the same patient), nephroblastoma $(\mathrm{n}=1)$ and pulmonary carcinoma $(\mathrm{n}=1)$.

Contact was done via telephone to determine any complication after the biopsy. No complications were reported. Patients with RCC were followed according to the guidelines of European Association of Urology (available on http:// www.uroweb.org/guidelines/online-guidelines). 
TABLE 1. Echoendoscopic ultrasonography with fine needle aspiration (EUS-FNA) renal biopsy

\begin{tabular}{|c|c|c|c|c|c|c|c|c|c|c|}
\hline $\begin{array}{c}\text { Biopsy } \\
\text { number }\end{array}$ & $\begin{array}{l}\text { Age/ } \\
\text { Sex }\end{array}$ & Clinical Picture & Indication & $\begin{array}{l}\text { Kidney } \\
\text { (side) }\end{array}$ & Kidney pole & $\begin{array}{c}\text { Diameter } \\
(\mathrm{cm})\end{array}$ & Final citology & Surgery & Histology & Follow-up \\
\hline 3 & $73 / \mathrm{M}$ & $\begin{array}{l}\text { Incidental, family } \\
\text { history RCC }\end{array}$ & $\begin{array}{c}\text { Oncocytoma vs } \\
\text { RCC }\end{array}$ & $\mathrm{L}$ & Inferior & 10 & Papillary RCC & $\begin{array}{c}\text { Yes (partial } \\
\text { nephrectomy) }\end{array}$ & RCC & $\begin{array}{l}\text { NED, } \\
2 \text { years }\end{array}$ \\
\hline 5 & $51 / \mathrm{M}$ & $\begin{array}{c}\text { Convulsion, brain } \\
\text { metastasis + renal } \\
\text { mass }\end{array}$ & $\begin{array}{l}\text { Histologic } \\
\text { diagnosis }\end{array}$ & $\mathrm{R}$ & Mesorenal & 5 & Clear cell RCC & No & - & $\begin{array}{l}\text { DOD, } \\
11 \text { months }\end{array}$ \\
\hline 6 & $50 / \mathrm{M}$ & $\begin{array}{c}\text { Macroscopic } \\
\text { hematuria }\end{array}$ & Small mass & $\mathrm{L}$ & Mesorenal & 1.3 & Clear cell RCC & $\begin{array}{c}\text { Yes (radical } \\
\text { nephrectomy) }\end{array}$ & $\mathrm{RCC}$ & $\begin{array}{l}\text { NED, } \\
2.5 \text { years }\end{array}$ \\
\hline 9 & $27 / M$ & Abdominal mass & $\begin{array}{l}\text { Nephroblastoma } \\
\text { vs RCC }\end{array}$ & $\mathrm{L}$ & Large mass & 8 & $\begin{array}{l}\text { Nephroblas- } \\
\text { toma }\end{array}$ & $\begin{array}{c}\text { Yes } \\
\text { (nephrectomy) }\end{array}$ & $\begin{array}{l}\text { Nephro- } \\
\text { blastoma }\end{array}$ & $\begin{array}{l}\text { DOD, } \\
6 \text { months }\end{array}$ \\
\hline 10 & $78 / \mathrm{M}$ & Abdominal pain & $\begin{array}{c}\text { Suspicion of } \\
\text { pulmonary cancer } \\
\text { metastasis to } \\
\text { kidney }\end{array}$ & $\mathrm{R}$ & Superior & 6 & $\begin{array}{l}\text { Pulmonary } \\
\text { carcinoma }\end{array}$ & No & - & $\begin{array}{l}\text { DOD, } \\
3 \text { months }\end{array}$ \\
\hline
\end{tabular}

M: male; RCC: renal cell carcinoma; R: right; L: left; NED: no evidence of disease; DOD: died of disease

\section{DISCUSSION}

More than 200.000 new cases of kidney cancer are diagnosed annually, with more than 100.000 related deaths per year worldwide. RCC accounts for 3\% of all adult malignancies and is increasing at a rate of $2.5 \%$ per year ${ }^{(1)}$.

An enhancing renal neoplasm on CT or MRI has been considered by most urologists to be a sufficient indication for surgery because about $80 \%$ of such lesions prove to be $\mathrm{RCC}^{(9)}$. Currently, if local experience is sufficient and the biopsy result has the potential to impact treatment decisions, urologists should consider increasing the use of core biopsy and FNA to better characterize suspicious renal masses preoperatively ${ }^{(2,12,14)}$. The advantages of a biopsy in these cases are the potential to decrease unnecessary treatment of small renal masses and better selection of tumors for active surveillance and minimally invasive ablative therapies ${ }^{(7,14)}$.

The role of needle core biopsy and FNA of renal masses is primarily to rule out non renal cell primary tumors (metastasis and lymphoma) or benign conditions (abscess), which may not require surgery ${ }^{(4)}$. Biopsy has also been used to confirm the diagnosis and the histological subtype of a renal primary lesion in patients with disseminated metastasis or unresectable retroperitoneal mass. In metastatic RCC, there is evidence that patients with clear cell subtype histology are more likely to benefit from adjuvant immunotherapy following cytoreductive nephrectomy ${ }^{(3)}$. A role for biopsy in the new target therapies demonstrate different response rates with different RCC subtypes ${ }^{(6)}$.
FNA with immunocytochemistry analysis can help distinguish between RCC and oncocytomas. Even though RCC may be present in as many as $18 \%$ of oncocytomas, a EUS FNA showing oncocytoma, might allow surveillance for a renal lesion, especially if the patient prefers conservative management ${ }^{(13)}$.

Percutaneous renal mass biopsy must not be performed routinely for renal lesions less than $40 \mathrm{~mm}$ but it should be indicated for incompletely accurate renal imaging diagnosis after a full imaging evaluation. Almost in $30 \%$ of the selected patients, a surgical procedure became no mandatory after renal biopsy results were obtained ${ }^{(9,11)}$.

The risk of complications associated with EUS FNA ranges from less than 1-6\%. Tracheal suction (5\%), vomiting $(0.3 \%)$, aspiration $(0.3 \%)$, esophageal perforation and death (less than $0.06 \%$ ) are reported complications of EUS. Tumor seeding is a potential unlikely complication of EUS FNA with few cases reported ${ }^{(5)}$. The incidence of hemorrhage after biopsy was low (1\%). In the current study, there were no complications reported.

Preoperative biopsy of renal masses should be indicated only in selected cases. Good results for EUS FNA of selected renal tumors were observed in this study. Our overall technical success rate of EUS-guided FNA was $90 \%$, which is within the range previously reported ${ }^{(1,2,4,14)}$. The cause of failed procedure was due to the posterior aspect of this tumor and the smaller needle-tumor distance. In this patient, it appears to us that a computerized tomography guided posterior renal biopsy should be more appropriate. Some renal masses may 
be unsuitable for EUS-guided biopsy because of anatomical limitations. Among other reasons, these limitations are likely to restrict widespread application of this method. EUS-FNA will be best applied to central anterior renal masses. For lesions on the posterior kidney aspect close to abdominal wall, percutaneous approach is probably the best choice.

EUS FNA appears as a safe and feasible procedure with good results, minimal morbidity and a short hospital stay ${ }^{(4)}$. Although this paper is the second largest case series of EUS FNA of renal masses in the literature and the first on a single-center, our results should be interpreted carefully, especially due to the small number of cases submitted to FNA. The most important questions pertain to the role of EUS-FNA of renal tumors and the patients most likely to benefit from the procedure.

Further research should evaluate the benefits of preoperative renal biopsy use and randomization of percutaneous, laparoscopic and echoendoscopic approach should be compared.

Moura RN, Lopes RI, Srougi MF, Dall'Oglio MF, Sakai P, Artifon ELA. Ecoendoscopia com punção aspirativa de massas renais: indicações, aplicações e limitações. Arq Gastroenterol. 2014,51(4):337-40.

RESUMO - Contexto - A amostragem de tecido de massas renais é tradicionalmente realizada através da abordagem percutânea ou pelo método laparoscópico. A utilidade do ultrassom endoscópico para biópsia de lesões renais ainda não está clara e poucos casos foram relatados na literatura. Objetivos - Avaliar a factibilidade e os resultados da biópsia de tumores renais guiada por ultrassom endoscópico. Método - Trata-se de uma série retrospectiva de casos de biópsias ecoguiadas de massa renal após avaliação com tomografia computadorizada ou ressonância magnética. Resultados - Dez procedimentos foram realizados em nove pacientes do sexo masculino (idade média de 54,7 anos), no rim direito $(n=4)$, esquerdo $(n=4)$ e bilateralmente $(\mathrm{n}=1)$. Massas renais (diâmetro médio $55 \mathrm{~mm}$; variando de 13 a $160 \mathrm{~mm})$ localizadas no pólo superior $(\mathrm{n}=3)$, inferior $(\mathrm{n}=2)$ e na região mesorenal $(\mathrm{n}=3)$. Em dois casos, a massa envolvida mais de uma região renal. A ressecção cirúrgica confirmou carcinoma de células renais em seis pacientes nos quais a biópsia ecoguiada pré-operatória demonstrava carcinoma de células renais. Não foram relatadas complicações. Conclusão - A biópsia de massas renais guiadas por ultrassom endoscópico é um procedimento seguro e viável, com bons resultados e mínima morbidade. DESCRITORES - Neoplasias renais, diagnósticos. Ultrassonografia. Aspiração por agulha fina guiada por ultrassom endoscópico

\section{REFERENCES}

1. Artifon ELA, Lopes RI, Kumar A, Lucon AM, Dall'oglio M, Hawan B, et al Endoscopic ultrasound facilitates histological diagnosis of renal cell cancer. Journal of Endourology. 2008;22:2447-50.

2. Bardales RH, Stelow EB, Maallery S, Lai R, Stanley MW. Review of endoscopic ultrasound-guided fine-needle aspiration cytology. Diagnostic Cytopathology. 2006;34:140-175.

3. Bex A, Horenblas S, Meinhardt W, Verra N, de Gast GC. The role of initial immunotherapy as selection for nephrectomy in patients with metastatic renal cell carcinoma and the primary tumor in situ. Eur Urol. 2002;42:570-6.

4. DeWitt J, Gress FG, Levy MJ, Hernandez LV, Eloubeidi MA, Mishra G, et al. EUS-guided FNA aspiration of kidney masses: a multicenter U.S experience. Gastrointest Endosc. 2009;70:573-8.

5. Doi S, Yasuda I, Iwashita T, Ibuka T, Fukushima H, Araki H, et al. Neddle tract implantation on the esophageal wall after EUS-guided FNA of metastatic mediastinal lymphadenopathy. Gastrointest Endosc. 2008;67:988-90.

6. Farrell JJ, Brugge WR. EUS-guided fine-needle aspiration of a renal mass: an alternative method for diagnosis of malignancy. Gastrointest Endosc. 2002;56:450-2.

7. Jhala NC, Jhala DN, Chhieng DC, Eloubeidi MA, Eltoum IA. Endoscopic ultrasound-guided fine-needle aspiration - A cytopathologist's perspective. Am J Clin Pathol. 2003;120:351-67.

8. Kutikov A, Fossett LK, Ramchandani P, Tomaszewski JE, Siegelman ES, Banner MP, et al. Incidence of bening pathologic findings at partial nephrectomy for solitary renal mass presumed to be renal cell carcinoma on preoperative imaging. Urology. 2006;68:737-40.
9. Lane BR, Samplaski MK, Herts BR, Zhou M, Novick AC, Campbell SC. Renal mass biopsy - a renaissance?. J Urol. 2008;179:20-7.

10. Lebret T, Poulain JE, Molinie V, Herve JM, Denoux Y, Guth A, et al. Percutaneous core biopsy for renal masses: indications, accuracy and results. J Urol. 2007; $178: 1184-8$

11. Lechevalier E, Andre M, Barriol D, Daniel L, Eghazarian C, De Fromont M, et al. Fine-needle percutaneous biopsy of renal masses with helical $\mathrm{Ct}$ guidance. Radiology. 2000;216:506-10.

12. Neuzillet Y, Lechevallier E, Andre M, Daniel L, Coulange C. Accuracy and clinical role of fine needle percutaneous biopsy with computerized tomography guidance of small (less than $4.0 \mathrm{~cm}$ ) renal masses. J Urol. 2004;171:1802-5.

13. Neuzillet Y, Lechevallier E, Andre M, Daniel L, Nahon O, Coulange C. Follow-up of renal oncocytoma diagnosed by percutaneous tumor biopsy. Urology. 2005;66:1181-5.

14. Volpe A, Kachura JR, Geddie WR, Evans AJ, Gharajeh A, Saravanan A, Jewett MA. Techiniques, safety and accuracy of sampling of renal tumors by fine needle aspiration and core biopsy. J Urol. 2007;178:379-86.

15. Wood BJ, Khan MA, McGovern F, Harisinghani M, Hahn PF, Mueller PR. Imaging guided biopsy of renal masses: indications, accuracy and impact on clinical management. J Urol. 1999;161:1470-4. 